\title{
PENGARUH PENERAPAN METODE PEMBELAJARAN LATIHAN TERHADAP HASIL BELAJAR PADA MATA PELAJARAN TEKNOLOGI DASAR OTOMOTIF
}

\author{
Syirojuddin Zikri ${ }^{1}$, Amay Suherman ${ }^{2}$, Tatang Permana ${ }^{3}$ \\ Universitas Pendidikan Indonesia \\ Jl. Dr. Setiabudhi No. 229 Bandung 40154 \\ zikrialfarizi17@gmail.com
}

\begin{abstract}
ABSTRAK
Tujuan penelitian ini, yaitu untuk mengetahui pengaruh penerapan metode pembelajaran drill terhadap hasil belajar siswa. Metode penelitian yang digunakan adalah metode quasi eksperimental dengan rancangan nonequivalent control group design. Penelitian ini digunakan dua kelas perlakuan sebagai kelas eksperimen dan kelas kontrol. Kelas eksperimen melakukan pembelajaran dengan menggunakan metode pembelajaran drill, dan kelas kontrol melakukan pembelajaran dengan menggunakan metode ceramah. Hasil perhitungan data hasil belajar kelas kontrol, diperoleh skor rata-rata data N-Gain siswa sebesar 0.47 dengan kategori sedang. Hasil observasi terhadap aktivitas siswa saat proses pembelajaran berlangsung dalam kelas kontrol, menunjukkan persentase banyak siswa yang bisa melakukan perhitungan dalam belajar momen sesuai opration manual sebesar $38.71 \%$. Hasil perhitungan data hasil belajar kelas eksperimen, diperoleh skor ratarata data N-Gain siswa sebesar 0.72 dengan kategori tinggi. Hasil observasi terhadap aktivitas siswa pada kelas eksperimen, menunjukkan persentase banyak siswa yang bisa melakukan perhitungan dalam belajar momen sesuai opration manual sebesar $84.37 \%$. Hasil pengujian hipotesis data N-Gain didapat nilai $t_{\text {hitung }}=$ $8.33>t_{\text {tabel }}=1.67 . \mathrm{H}_{\mathrm{o}}$ ditolak sehingga mengambil $\mathrm{H}_{\mathrm{A}}$, yaitu terdapat perbedaan peningkatan hasil belajar antara kelas eksperimen yang menerapkan metode drill, dengan kelas kontrol yang menggunakan metode ceramah yang signifikan. Penelitian ini, dapat disimpulkan bahwa ada pengaruh positif dari penerapanan metode pembelajaran $d r i l l$ terhadap hasil belajar pada mata pelajaran teknologi dasar otomotif.
\end{abstract}

Kata kunci: metode pembelajaran, drill, hasil belajar, teknologi dasar otomotif.

\section{PENDAHULUAN}

Kurikulum Teknik Kendaraan Ringan (TKR) SMK Negeri 6 Bandung menyatakan bahwa: proses pembelajaran dikembangkan menyesuaikan dengan Kurikulum 2013. Proses pembelajaran yang berpusat pada guru menjadi pembelajaran berpusat pada peserta didik. Proses pembelajaran satu arah (interaksi guru-peserta didik) menjadi pembelajaran interaktif (interaktif guru-peserta didik-masyarakat lingkungan alam, sumber/media lainnya). Proses pembelajaran pasif menjadi pembelajaran aktif-mencari (pembelajaran siswa aktif mencari semakin diperkuat dengan model dan metode pembelajaran dengan pendekatan sains).

Proses pembelajaran pada kelas X TKR SMK Negeri 6 Bandung, yang sering digunakan dalam pembelajaran yaitu metode ceramah. Proses pembelajaran dengan metode ceramah tersebut masih berpusat pada guru, bertolak belakang dengan proses pembelajaran atau penggunaan metode pembelajaran menurut kurikulum TKR SMK

\footnotetext{
${ }^{1}$ Mahasiswa Dapartemen Pendidikan Teknik Mesin FPTK UPI

${ }^{2}$ Dosen Dapartemen Pendidikan Teknik Mesin FPTK UPI

${ }^{3}$ Dosen Dapartemen Pendidikan Teknik Mesin FPTK UPI
} 
Negeri 6 Bandung disesuaikan dengan kurikulum 2013, yang dituntut berpusat pada siswa. Hasil belajar siswa pada mata pelajaran teknologi dasar otomotif kelas X TKR SMK Negeri 6 Bandung, ketuntasannya didasarkan pada Permendikbud Tentang Penilaian Hasil Belajar oleh Pendidik Pada Pendidikan Dasar dan Pendidikan Menengah Nomor 104 Bagian III. E. 2 tahun 2014 yang menegaskan Ketuntasan Belajar untuk pengetahuan ditetapkan dengan skor rerata 2.67 untuk keterampilan ditetapkan dengan capaian optimum 2.67. Hal tersebut, menuntut seluruh siswa untuk mampu mendapatkan hasil belajar sesuai Ketuntasan Belajar/Kriteria Ketuntasan Minimal (KKM) yang telah ditetapkan tersebut. Informasi terkait hasil belajar siswa pada mata pelajaran teknologi dasar otomotif, masih perlu ditingkatkan. Jumlah siswa yang mencapai KKM sebanyak 36,11\% dan Jumlah siswa yang tidak mencapai KKM sebanyak 63,89\%.

Kondisi tersebut memberikan gambaran adanya masalah. Satu pihak metode yang digunakan guru tidak tepat dengan tuntutan kurikulum dan karakteristik mata pelajaran teknologi dasar otomotif, belum ada orientasi belajar dengan latihan yang teratur. Di pihak lain hasil belajar siswa masih rendah, rata-rata dibawah standar KKM. Faktor yang mepengaruhi masalah hasil belajar tersebut, diantaranya adalah penggunaan metode pembelajaran. Penggunaan dan penguasaan metode mengajar guru, motivasi belajar siswa, dan media pebelajaran yang digunakan guru dapat mempengaruhi hasil belajar siswa (Siswanto, 2016).

Penggunaan metode pembelajaran ceramah, siswa hanya fokus terhadap apa yang disampaikan guru mata pelajaran. Sejalan dengan pendapat ahli menyebutkan yang dimaksud dengan ceramah sebagai metode mengajar ialah penerangan dan penuturan secara lisan oleh guru terhadap kelasnya (Suryosubroto, 2009). Lebih lanjut, materi yang dikuasai siswa dari hasil ceramah akan terbatas pada yang dikuasai guru. Melalui ceramah, sangat sulit untuk mengetahui apakah seluruh siswa sudah mengerti apa yang dijelaskan atau belum (Sanjaya, 2006).

Alternatif metode yang dapat diterapkan oleh guru dalam pembelajaran, adalah melaksanakan pembelajaran teknologi dasar otomotif dengan menerapkan metode pebelajaran latihan (drill). Metode drill (latihan) merupakan suatu teknik mengajar dimana siswa melaksanakan kegiatan-kegiatan latihan, agar siswa memiliki ketangkasan atau keterampilan yang lebih tinggi dari apa yang telah dipelajari. Lebih lanjut, kelebihan metode drill adalah untuk memperoleh kecakapan motorik, seperti menulis, melafalkan huruf, kata-kata atau kalimat, membuat alat, menggunakan (mesin permainan dan atletik), 
dan terampil menggunakan alat olahraga, dan untuk memperoleh kecakapan mental, seperti dalam perkalian, menjumlahkan, pengurangan, pembagian, tanda-tanda (simbol).

Menerapkan metode pembelajaran drill, pelaksanaanya diarahkan berpusat pada siswa, yaitu siswa akan diberikan pemahaman secara bertahap dan teratur dengan melakukan kegiatan-kegiatan latihan terhadap materi yang diajarkan, sehingga materi cepat dipahami dan lebih melekat dalam pikiran siswa. Metode drill, memiliki kelebihan sesui dengan karakteristik mata pelajaran dengan bahan ajar untuk memperoleh kecakapan mental, yaitu belajar perkalian, menjumlahkan, pengurangan, pembagian atau belajar rumus-rumus dan perhitungan. Menerapkan metode drill, memungkinkan siswa dapat mencapai hasil belajar sesuai harapan, dan memungkinkan siswa bisa belajar rumus-rumus dan perhitungan dengan sangat baik pada mata pelajaran teknologi dasar otomotif.

Siswa baru mendapatkan mata pelajaran teknologi dasar otomotif materi memahami dasar-dasar mesin pokok bahasan momen. Hasil belajar siswa sebelum proses pembelajaran dapat terukur melalui pretest. Hasil belajar sebenarnya yang diperoleh dari proses pembelajaran adalah, besarnya peningkatan kemampuan siswa yang diperoleh dari kemampuan awal yang diukur melalui pretest menjadi penguasaan materi yang diukur melalui posttest. Sejalan dengan pengertian belajar adalah suatu proses untuk memperoleh pengetahuan, meningkatkan keterampilan, memperbaiki perilaku, sikap dan mengokohkan keperibadian (Suyono \& Hariyanto, 2011).

Pembelajaran teknologi dasar otomotif, agar bisa berjalan dengan baik tentu pembelajarannya harus direncanakan dengan baik antara siswa, guru, lingkungan serta fasilitas belajar yang saling berkaitan dan mempengaruhi untuk mencapai tujuan belajar (Aunurrahman, 2009). Pembelajaran teknologi dasar otomotif, awalnya masih berpusat pada guru (teacher centered), diarahkan berpusat pada siswa (student centered). Sejalan dengan Permendikbud Tentang Krangka Dasar dan Struktur Kurikulum Sekolah Menengah Kejuruan/Madrasah Aliyah Kejuruan No. 70 tahun 2013 menyatakan bahwa proses pembelajaran yang berpusat pada guru menjadi pembelajaran berpusat pada peserta didik. Pembelajaran yang telah direncanakan agar dapat tercapai dan berpusat pada siswa, diperlukan metode pembelajaran yang tepat. Sejalan dengan pendapat yang menyebutkan bahwa metode digunakan untuk merealisasikan rencana yang telah ditetapkan (Majid, 2013). Metode dari masing-masing pelajaran pasti berbeda, oleh karena itu metode pembelajaran yang dipilih harus sesuai dengan sifat materi pelajaran tersebut (Sumiati dan Asra, 2014). Penelitian ini, disesuaikan dengan karakteristik materi pelajaran teknologi dasar otomotif. 
Pemilihan metode pembelajaran yang sesuai pada penelitian ini, ditujukan agar dapat berpengaruh positif terhadap tujuan dan hasil belajar pada mata pelajaran teknologi dasar otomotif yang diharapkan. Sejalan denganpen dapat yang enyebutkan bahwa faktor yang mepengaruhi hasil belajar, diantaranya adalah metode pembelajaran (Susanto, 2013). Hasil belajar penelitian ini diperoleh dari data tes berupa soal essay dan observasi aktivitas siswa. Sejalan dengan pendapat yang menyebutkan bahwa hasil belajar sesuatu yang diperoleh dari suatu proses usaha setelah melakukan kegiatan belajar yang dapat diukur dengan menggunakan tes. Tes hasil belajar itu sendiri adalah sekelompok pertanyaan atau tugas-tugas yang harus dijawab atau diselesaikan oleh siswa dengan tujuan mengukur kemajuan belajar siswa (Slameto, 2008).

\section{METODE PENELITIAN}

Metode penelitian yang digunakan dalam penelitian ini adalah quasi eksperimental dan desain penelitian dengan rancangan nonequivalent control group design. Melalui desain ini subyek dibagi menjadi dua kelas yaitu kelas pertama diberi perlakuan (X) sebagai kelas eksperimen dan kelas yang lain tidak diberi perlakuan sebagai kelas kontrol. Populasi dalam penelitian ini adalah seluruh siswa kelas X TKR tahun ajaran 2016/2017 di SMK N 6 Bandung. Jumlah keseluruhan sampel sebanyak 218 siswa. Pengambilan sampel yang digunakan dalam penelitian ini adalah teknik cluster sampling. Teknik cluster sampling digunakan untuk menentukan sampel apabila obyek yang akan diteliti atau sumber data sangat luas. Ditentukan kelas X TKR 2 sebagai kelas eksperimen, dan kelas X TKR 3 sebagai kelas kontrol.

Instrumen dalam penelitian ini adalah tes dan lembar observasi. Instrumen pembelajaran berupa Rencana Pelaksanaan Pembelajaran (RPP) dan Lembar Kegiatan Siswa (LKS). Pengujian kelayakan instrumen dengan melakukan validitas ahli (expert judgment) dibidangnya, yaitu judgment ahli RPP dan judgment ahli mata pelajaran teknologi dasar otomotif. Menganalisis data hasil belajar dalam penelitian ini yaitu dengan memeriksa jawaban pretest, posttest dan lembar observasi. Data yang sudah dikumpulkan dianalisis secara deskriptif, dilanjutkan uji homogenitas data, uji normalitas dan uji N-Gain, serta uji hipotesis menggunakan uji-t. 


\section{HASIL PENELITIAN}

Data hasil belajar dan data hasil observasi kelas kontrol, diperoleh dari data hasil tes dan hasil observasi yang kemudian dilakukan analisis secara deskriptif. Hasil analisis data hasil belajar dan data observasi kelas kontrol ada pada Tabel 1.

Tabel 1. Hasil belajar dan observasi kelas kontrol

\begin{tabular}{|c|c|c|c|c|c|c|}
\hline Data & Minimal & Maksimal & Rata-Rata & Kategori & $\mathrm{F}$ & $\mathrm{F}(\%)$ \\
\hline \multirow{2}{*}{ Pretest } & \multirow{2}{*}{1.09} & \multirow{2}{*}{1.63} & \multirow{2}{*}{1.27} & Kompeten $(\mathrm{K})$ & - & - \\
\hline & & & & Belum Kompeten (BK) & 31 & 100 \\
\hline \multirow{2}{*}{ Posttest } & \multirow{2}{*}{2.18} & \multirow{2}{*}{3.00} & \multirow{2}{*}{2.57} & Kompeten $(\mathrm{K})$ & 11 & 35.48 \\
\hline & & & & Belum Kompeten (BK) & 20 & 64.52 \\
\hline N-Gain & \multirow[t]{5}{*}{0.30} & \multirow[t]{5}{*}{0.61} & \multirow[t]{5}{*}{0.47} & $\begin{array}{l}\text { Tinggi } \\
\text { Sedang } \\
\text { Rendah }\end{array}$ & $\begin{array}{l}- \\
31 \\
-\end{array}$ & 100 \\
\hline \multirow{4}{*}{ Observasi } & & & & Sangat Baik (SB) & 12 & 38.71 \\
\hline & & & & Baik (B) & 16 & 51.61 \\
\hline & & & & Cukup (C) & 3 & 9.68 \\
\hline & & & & Kurang (K) & - & - \\
\hline
\end{tabular}

Hasil analisis data hasil belajar dan data observasi kelas kontrol di atas, pada pretest diperoleh skor terbesar 1.63, skor terkecil 1.09, dan skor rata-rata data pretest sebesar 1.27. Menunjukkan hasil belajar semua siswa belum ada yang kompeten sebelum pemberian perlakuan/pembelajaran. Skor pada data posttest, diperoleh skor terbesar 3.0, skor terkecil 2.18 , dan skor rata-rata data pretest sebesar 2.57, dengan persentase banyak siswa yang kompeten sebesar $35.48 \%$, dan persentase banyak siswa yang belum kompeten $64.52 \%$ setelah pemberian perlakuan/pembelajaran. Skor N-Gain pada kelas kontrol, diperoleh NGain terbesar 0.61, N-Gain terkecil 0.30 dan skor rata-rata data N-Gain siswa sebesar 0.47 dengan kategori sedang. Hasil observasi terhadap aktivitas siswa saat proses pembelajaran berlangsung dalam kelas kontrol, menunjukkan persentase banyak siswa yang mendapatkan predikat SB hanya sebesar $38.71 \%$, persentase predikat B sebesar $51.61 \%$, dan persentase predikat $\mathrm{C}$ sebesar $9.68 \%$.

Hasil data pada kelas eksperimen, cara mengolah datanya sama dengan yang dilakukan pada kelas kontrol, yaitu secara deskriptif. Hasil analisis data hasil belajar dan data observasi pada kelas eksperimen, dapat dilihat pada Tabel 2. 
Tabel 2. Hasil belajar dan observasi kelas eksperimen

\begin{tabular}{cccclcc}
\hline Data & Minimal & Maksimal & Rata-Rata & \multicolumn{1}{c}{ Kategori } & F & F (\%) \\
\hline \multirow{2}{*}{ Pretest } & \multirow{2}{*}{1.09} & \multirow{2}{*}{1.63} & \multirow{2}{*}{1.38} & Kompeten (K) & - & - \\
& & & & Belum Kompeten (BK) & 32 & 100 \\
Posttest & \multirow{2}{*}{2.54} & \multirow{2}{*}{3.82} & \multirow{2}{*}{3.27} & Kompeten (K) & 26 & 81.25 \\
& & & & Belum Kompeten (BK) & 6 & 18.75 \\
N-Gain & \multirow{2}{*}{0.48} & \multirow{2}{*}{0.92} & \multirow{2}{*}{0.72} & Tinggi & 21 & 65.63 \\
& & & & Sedang & 11 & 34.37 \\
& & & & Rendah & - & - \\
Observasi & & \multirow{2}{*}{} & & Sangat Baik (SB) & 27 & 84.37 \\
& & & & Cukup (C) & 5 & 15.63 \\
& & & & Kurang (K) & - & - \\
\hline
\end{tabular}

Hasil analisis data hasil belajar dan data observasi pada kelas eksperimen, pada pretest diperoleh skor terbesar 1.63, skor terkecil 1.09, dan skor rata-rata data pretest sebesar 1.38. Menunjukkan hasil belajar semua siswa belum ada yang kompeten sebelum pemberian perlakuan/pembelajaran. Skor pada data posttest, diperoleh skor terbesar 3.82, skor terkecil 2.54, dan skor rata-rata data pretest sebesar 3.27, dengan persentase banyak siswa yang kompeten sebesar $81.25 \%$, dan persentase banyak siswa yang belum kompeten $18.75 \%$ setelah pemberian perlakuan/pembelajaran. Skor N-Gain pada kelas kontrol, diperoleh skor N-Gain terbesar 0.92, skor N-Gain terkecil 0.48 dan skor rata-rata data NGain siswa sebesar 0.72 dengan kategori tinggi. Hasil observasi terhadap aktivitas siswa pada kelas eksperimen, menunjukkan persentase banyak siswa dengan predikat sangat baik sebanyak $84.37 \%$, dan yang mendapatkan predikat baik sebanyak $15.63 \%$.

Hasil perhitungan uji homogenitas data pretest ditentukan dengan menggunakan uji F. Pengujian dilakukan dengan menggunakan taraf signifikan 0.05 dan derajat kebebasan $\mathrm{dk}=31$ untuk kelas eksperimen dan $\mathrm{dk}=30$ untuk kelas kontrol. Diperoleh $\mathrm{F}_{\text {hitung }}=1,04$ nilai ini berada pada $p$-value $=0,11$. Karena $\mathrm{F}_{\text {hitung }}=1,04<\mathrm{F}_{\text {tabel }}=1,83$ dan $p$-value $=0,11$ $>\alpha=0,05$ terletak pada penerimaan homogen, dapat disimpulkan bahwa pretest kelas eksperimen dan kelas kontrol adalah homogen. Data pretest kedua sampel homogen pada taraf signifikansi 95\%. Pelaksanaan eksperimen dapat dilakukan pada kedua kelas tersebut.

Uji normalitas data skor N-Gain ditentukan dengan menggunakan uji kecocokan chikuadrat. Uji normalitas peningkatan hasil belajar (N-Gain) untuk kelas eksperimen diperoleh $\chi_{\text {hitung }}^{2}=5,34$, nilai ini berada pada $p$-value $=0,08$ untuk $\mathrm{dk}=\mathrm{k}-3$. Karena $p$ value $=0,8>\alpha=0.05$ terletak pada penerimaan normal. Kondisi data N-Gain kelas kontrol 
berdistribusi normal pada taraf signifikansi $8 \%$. Kelas kontrol diperoleh nilai $\chi^{2}{ }_{\text {hitung }}=$ 2.05, nilai ini berada pada $p$-value $=0.11$ untuk $\mathrm{dk}=\mathrm{k}-3$. Karena $p$-value $=0.11>\alpha=0.05$ terletak pada penerimaan normal. Kondisi data N-Gain kelas yang menerapkan metode pembelajaran drill berdistribusi normal pada taraf signifikansi $95 \%$.

Uji hipotesis dilakukan untuk melihat perbedaan pengaruh penerapan metode pembelajaran drill terhadap peningkatan hasil belajar dibandingkan dengan menggunakan metode pembelajaran ceramah. Asumsi statistik diantaranya homogenitas dan normalitas terpenuhi maka pengujian hipotesis menggunakan stastistik Uji-t. Hasil pengujian hipotesis untuk peningkatan hasil belajar $\left(\mathrm{N}\right.$-Gain) didapat nilai $t_{\text {hitung }}=8.33>t$ tabel $=1.67 . \mathrm{H}_{\mathrm{o}}$ ditolak sehingga mengambil $\mathrm{H}_{\mathrm{A}}$, yaitu terdapat perbedaan peningkatan hasil belajar antara kelas eksperimen yang menerapkan metode pembelajaran drill, dengan kelas kontrol yang menggunakan metode ceramah yang signifikan.

\section{PEMBAHASAN}

Proses pembelajaran teknologi dasar otomotif, pengaruh penggunaan metode pembelajaran yang biasa digunakan guru yaitu metode ceramah. Terlihat peningkatan hasil belajar siswa dalam kategori sedang dan aktivitas siswa rata-rata mendapat predikat baik. Hasil tersebut, menunjukkan masih belum sesuai dengan harapan. Penggunaan metode pembelajaran ceramah, siswa hanya fokus terhadap apa yang disampaikan guru mata pelajaran. Sejalan dengan pendapat ahli menyebutkan yang dimaksud dengan ceramah sebagai metode mengajar ialah penerangan dan penuturan secara lisan oleh guru terhadap kelasnya (Suryosubroto, 2009). Lebih lanjut, materi yang dikuasai siswa dari hasil ceramah akan terbatas pada yang dikuasai guru. Melalui ceramah, sangat sulit untuk mengetahui apakah seluruh siswa sudah mengerti apa yang dijelaskan atau belum (Sanjaya, 2006). Metode ceramah, dapat disimpulkan tidak tepat digunakan karena bertolak belakang dengan tuntutan kurikulum dan karakteristik mata pelajaran teknologi dasar otomotif, sehingga berakibat pada perolehan hasil belajar siswa tidak sesuai harapan.

Pembelajaran teknologi dasar otomotif, dalam pelaksanaannya peneliti menerapkan metode pembelajarn drill. Proses pembelajaran teknologi dasar otomotif, dengan penerapan metode pembelajaran drill terlihat peningkatan hasil belajar siswa dalam kategori tinggi dan aktivitas siswa rata-rata mendapat predikat sangat baik. Hasil tersebut, menunjukkan bahwa hasil belajar siswa dapat mencapai sesuai dengan harapan. Menerapkan metode pembelajaran drill, siswa diberikan pemahaman secara bertahap dan 
teratur dengan membiasakan melakukan kegiatan-kegiatan latihan baik secara berkelompok atau secara individu, sehingga materi yang diajarkan cepat dipahami dan lebih melekat dalam pikiran siswa. Selain itu, metode pembelajaran drill memiliki banyak kelebihan, diantaranya cocok digunakan pada mata pelajaran dengan bahan ajar untuk memperoleh kecakapan mental, yaitu belajar perkalian, menjumlahkan, pengurangan, pembagian atau belajar rumus-rumus dan perhitungan. Sejalan dengan pendapat bahwa metode drill yang disebut juga training merupakan suatu cara mengajar yang baik untuk menanamkan kebiasaan-kebiasaan tertentu. Juga sebagai sarana untuk memelihara kebiasaan-kebiasaan yang baik. Selain itu metode ini juga baik untuk memperoleh suatu ketangkasan, ketepatan, kesempatan dan keterampilan. Siswa juga dapat memperoleh kecakapan mental (Djamarah dan Zain, 2010). Metode pembelajaran drill, dapat disimpulkan sesuai dengan karakteristik mata pelajaran teknologi dasar otomotif yang bahan ajarnya banyak untuk memperoleh kecakapan mental, dan sejalan dengan tuntutan kurikulum. Terbukti berpengaruh terhadap hasil belajar siswa yang lebih baik dan lebih meningkat.

Perbedaan pengaruh penerapkan metode pembelajaran drill pada mata pelajaran teknologi dasar otomotif, menunjukkan peningkatan hasil belajar siswa lebih tinggi di bandingkan dengan menggunakan metode pembelajaran ceramah. Pengujian hipotesis menunjukkan terdapat perbedaan yang signifikan, antara hasil belajar kelas yang menggunakan metode pembelajaran drill dengan kelas yang menggunakan metode pembelajaran ceramah. Sejalan dengan penelitian yang terdahulu, diantaranya menyimpulkan terdapat perbedaan yang berarti antara peningkatan prestasi belajar siswa yang pembelajarannya menggunakan metode drill dengan yang tidak menggunakan metode drill (Ramdhani, 2012). Penerapan metode drill dapat meningkatkan prestasi belajar siswa (Sutarmiyati, 2016). Peningkatan hasil belajar, pemahaman dan keterampilan dalam belajar terjadi ketika seseorang membiasakan untuk terus belajar dengan melakukan latihan-latihan secara teratur terhadap materi yang diajarkan. Penerapan metode pembelajaran drill pada penelitian ini, ternyata dapat memberikan pengaruh positif terhadap hasil belajar pada mata pelajaran teknologi dasar otomotif siswa kelas X SMK Negeri 6 Bandung.

\section{KESIMPULAN}

Peneliti dapat disimpulan sebagai berikut: pengaruh positif penerapan metode pembelajaran drill yang ditimbulkan merupakan akibat dari siswa yang melakukan latihan 
yang teratur terhadap materi pada mata pelajaran teknologi dasar otomotif. Siswa dapat memahami materi belajar dengan sangat baik dan peningkatan rata-rata hasil belajar yang dicapai lebih tinggi, dibandingkan dengan menggungakan metode pembelajaran ceramah. Pengaruh penggunaaan metode pembelajaran ceramah peningkatan hasil belajar siswa mencapai rata-rata dalam kategori sedang, dan aktivitas siswa rata-rata mendapatkan predikat baik. Pengaruh penerapan metode pembelajaran drill peningkatan hasil belajar siswa mencapai rata-rata dalam kategori tinggi, dan aktivitas siswa rata-rata mendapatkan predikat sangat baik. Pengaruh penerapan metode pembelajaran drill terhadap peningkatan hasil belajar lebih tingggi, dibandingkan dengan penerapan metode pembelajaran ceramah dalam proses pembelajaran. Penerapan metode drill menunjukkan terdapat perbedaan yang signifikan, antara hasil belajar kelas eksperimen, yaitu kelas yang menggunakan metode pembelajaran drill dengan kelas kontrol, yaitu kelas yang menggunakan metode pembelajaran ceramah.

\section{REFERENSI}

Aunurrahman. (2009). Belajar dan pembelajaran. Bandung: Alfabeta.

Djamarah, S.B. dan Zain, A. (2010). Strategi Belajar Mengajar. Jakarta: Rineka Cipta.

Majid, A. (2013). Strategi Pembelajaran. Bandung: PT Remaja Rosdakarya.

Sanjaya, W. (2006). Strategi Pembelajaran. Jakarta: Kencana Prenada Media Group.

Sutrisno, V.L.P. dan Siswanto, B.T. (2016). Faktor-Faktor yang Mempengaruhi Hasil Belajar Siswa pada Pembelajaran Praktik Kelistrikan Otomotif SMK di Kota Yogyakarta. Jurnal Pendidikan Vokasi. 6 (1).

Slameto. (2008). Proses Belajar Mengajar. Jakarta: Remaja Rosdakarya.

Sumiati dan Asra. (2014). Metode Pembelajaran. Bandung: CV Wacana Prima.

Suryosubroto, B. (2009). Proses Belajar Mengajar di Sekolah. Jakarta: Rineka Cipta.

Susanto, A. (2013). Teori Belajar dan Pembelajaran di Sekolah Dasar. Jakarta: Kencana.

Sutarmiyati. (2016). Penggunaaan Metode Drill pada Materi Ajar Penjumlahan Bilangan Pecahan. Journal Penelitian Pendidikan Indonesia, 1 (1).

Suyono dan Hariyanto. (2011). Belajar dan Pembelajaran. Bandung: Remaja Rosdakarya. 